\title{
Proapoptotic effects of 2,5-hexanedione on pheochromocytoma cells via oxidative injury
}

\author{
BAONING QI ${ }^{1}$, SHOUZHU XU ${ }^{1}$, YUAN LIANG ${ }^{2}$, JIAXIN WANG ${ }^{1}$, ZHIGANG ZHANG ${ }^{1}$, JUAN LI ${ }^{1}$ and JING ZHOU ${ }^{1}$ \\ ${ }^{1}$ Department of Public Health, Shaanxi University of Chinese Medicine, Xianyang, Shaanxi 712046; \\ ${ }^{2}$ Genetic Medical Center, The Northwest Women's and Children's Hospital, Xi'an, Shaanxi 710061, P.R. China
}

Received October 31, 2018; Accepted July 7, 2019

DOI: $10.3892 / \mathrm{mmr} .2019 .10546$

\begin{abstract}
N-hexanes are prominent environmental pollutants that are able to cause neurotoxicity in vivo and in vitro. Central and peripheral neuropathies induced by n-hexane exposure are a major health concern. 2,5-Hexanedione (2,5-HD) is the most significant neurotoxic metabolite of $n$-hexane; however, little is known regarding the underlying mechanism of its neurotoxicity. Thus, the aim of the present study was to investigate the damaging effects of 2,5-HD on pheochromocytoma PC12 cells, and to explore the underlying mechanism. Cell viability was tested using a Cell Counting Kit-8 method, and the leakage of lactate dehydrogenase (LDH) from cells was measured using an LDH assay kit. Glutathione peroxidase (GSHPx) and superoxide dismutase (SOD) activities, and the level of malondialdehyde (MDA) were determined using corresponding assay kits. Apoptotic cells were detected using an annexin V-fluorescein isothiocyanate/propidium iodide (PI) apoptosis kit, and were subsequently observed by fluorescence microscopy. The relative expression levels of cleaved-caspase-3, Bcl-associated-X protein (Bax) and $\mathrm{Bcl}-2$ were identified by western blotting. The results revealed that 2,5-HD was able to decrease the viability of PC12 cells and promoted the leakage of $\mathrm{LDH}$ in a concentrationdependent manner. Further analysis demonstrated that 2,5-HD decreased the activity of the antioxidative enzymes, SOD and GSHPx, and led to an increase in the levels of MDA in the supernatant of cultured PC12 cells. The annexin V/PI staining results revealed that the numbers of apoptotic cells were increased following treatment with 2,5-HD. In addition, 2,5-HD (5 and $10 \mathrm{mmol} / \mathrm{l}$ ) led to significant increases in the expression levels of caspase- 3 and Bax, with the concomitant downregulation of Bcl-2. The antioxidant $\mathrm{N}$-acetylcysteine was identified to antagonize 2,5-HD-stimulated cleaved-caspase-3 and Bax
\end{abstract}

Correspondence to: Professor Shouzhu Xu, Department of Public Health, Shaanxi University of Chinese Medicine, 1 Shiji Ave, Xianyang, Shaanxi 712046, P.R. China

E-mail: xsz90026@163.com

Key words: 2,5-hexanedione, apoptosis, pheochromocytoma cells, oxidative stress upregulation, and Bcl-2 downregulation. Collectively, the results of the present study suggested that 2,5-HD exerts proapoptotic effects on PC12 cells via oxidative injury. These findings may be applied in the development of novel therapeutic strategies to treat neurological disorders associated with nhexane exposure.

\section{Introduction}

n-Hexanes are organic solvents that act as environmental pollutants, and have been demonstrated to cause neurotoxicity in vivo and in vitro (1). At present, central and peripheral neuropathies caused by nhexane present a major health concern (2-4). 2,5-Hexanedione (2,5-HD), the most significant neurotoxic metabolite of $n$-hexane, is involved in mediating this neurotoxicity $(5,6)$. Previously published data from experimental and clinical studies have revealed that cell apoptosis induced by 2,5-HD is the major cause of the pathophysiological changes associated with reactive oxygen species (7). It is well established that apoptosis is mediated by several different pathways, with the mitochondrial pathway, which is involved in cell apoptosis (8). Previously published data have shown that perturbations in the mitochondrial-mediated pathway lead to the dysregulated expression of proteins, including Bcl-2-associated $\mathrm{X}$ protein (Bax) and $\mathrm{Bcl}-2$, an increased rate mitochondrial cytochrome $c$ release, an increase in the loss of mitochondrial transmembrane potential and the activation of caspase-3; these processes are all associated with cell apoptosis $(9,10)$. Zhang et al (11) recently demonstrated that the cell injury induced by $2,5-\mathrm{HD}$ is mainly mediated via the regulation of mitochondrial-dependent apoptosis.

The clonal line PC12, originally derived from a solid rat adrenal medulla tumor, has been widely used as a dopaminergic neuronal model for in vitro studies, and also serves as a principal cell model for investigations in molecular neuroscience $(12,13)$. In addition, PC12 cells present as an excellent in vitro model to investigate certain aspects of various neurological disorders, including glutamate excitotoxicity (14), Parkinson's disease (15), Alzheimer's disease (16), and epilepsy (17); these cells have been reported to be useful in analyzing oxidative-stress-associated effects on neuronal cell survival (18-20). The production of reactive oxygen species (ROS) induced by environmental toxicants may elicit oxidative stress, which subsequently induces a state of imbalance 
between the antioxidant defense system and the generation of free radicals (21). ROS serve an important role in cell signal-transduction pathways, thereby mediating numerous pathological and physiological processes (22). A number of previously published studies have indicated that oxidative stress acts as a trigger for cell apoptosis $(23,24)$, and pretreatment with the antioxidant, $\mathrm{N}$-acetylcysteine (NAC), can effectively reverse ROS-induced cell apoptosis $(25,26)$. Thus, the aim of the present study was to examine the proapoptotic effects of 2,5-HD on pheochromocytoma PC12 cells, and to investigate the underlying mechanism. Taken together, the results obtained suggested that 2,5-HD is able to promote the proapoptotic effects on PC12 cells via oxidative injury. Our findings may contribute towards the development of novel strategies to treat neurological disorder diseases induced by n-hexane.

\section{Materials and methods}

Reagents and cell culture. RPMI-1640 medium and fetal bovine serum (FBS) were purchased from Gibco (Thermo Fisher Scientific, Inc.). Rabbit cleaved-caspase-3 (cat. no. AC033) and Bcl-2 (cat. no. AB112) antibodies, mouse Bax (cat.no. AF0054) and $\beta$-actin (cat.no. AA128) antibodies were obtained from Beyotime Institute of Biotechnology. Assay kits for detecting superoxide dismutase (SOD; cat. no. A001-3), malondialdehyde (MDA; cat. no. A003-1) and glutathione peroxidase (GSH-Px; cat. no. A005) were purchased from Nanjing Jiancheng Bioengineering Institute. 2,5-HD ( $\geq 99.0 \%$ purity; cat. no. 00770) was purchased from Sigma-Aldrich (Merck KGaA). All reagents for cell culture were of tissue culture grade, and all other reagents were purchased from Sigma-Aldrich (Merck KGaA), except where indicated; all were of analytical grade.

Pheochromocytoma cells (PC12 cells) were originally obtained from the American Type Culture Collection. Cells were cultured in RPMI-1640 medium supplemented with $10 \%$ FBS, and $100 \mathrm{U} / \mathrm{ml}$ penicillin and streptomycin, and maintained at $37^{\circ} \mathrm{C}$ in a humidified atmosphere with $5 \% \mathrm{CO}_{2}$. Prior to the experiments, cells were cultured in RPMI-1640 medium with $1 \%$ FBS for $12 \mathrm{~h}$. In the present study, the condition of the controls comprised cells that were cultured in RPMI-1640 medium with $100 \mathrm{U} / \mathrm{ml}$ penicillin and streptomycin, and maintained at $37^{\circ} \mathrm{C}$ in a humidified atmosphere with $5 \%$ $\mathrm{CO}_{2}$; durations of treatment was consistent with the 2,5-HD treatment group. To investigate whether oxidative stress is the underlying cause of 2,5-HD-induced cell apoptosis, the cells were pretreated with $10 \mathrm{mmol} / 1 \mathrm{NAC}$ for $1.5 \mathrm{~h}$ at $37^{\circ} \mathrm{C}$. Subsequently, the cells were exposed to $5 \mathrm{mmol} / 12,5-\mathrm{HD}$ or RPMI-1640 medium, which served as control treatment, for $12 \mathrm{~h}$ at $37^{\circ} \mathrm{C}$ in a humidified atmosphere with $5 \% \mathrm{CO}_{2}$.

Cell viability assay. Cell viability was performed using Cell Counting Kit-8 (CCK-8) assay (KA1606; Abnova Corporation). PC12 cells $\left(1-1.5 \times 10^{5} / \mathrm{ml}\right)$ were seeded into 96-well plates in the presence of different concentrations of 2,5 HD $(0.1-20 \mathrm{mmol} / \mathrm{l})$ at $37^{\circ} \mathrm{C}$ in a humidified atmosphere with $5 \% \mathrm{CO}_{2}$ for the indicated time periods. Subsequently, 20-200 $\mu \mathrm{l} \mathrm{CCK8} \mathrm{medium} \mathrm{per} \mathrm{well} \mathrm{was} \mathrm{added,} \mathrm{and} \mathrm{the} \mathrm{mixture}$ was incubated for a further $4 \mathrm{~h}$ at $5 \% \mathrm{CO}_{2}$ in an incubator at $37^{\circ} \mathrm{C}$. Optical density values were then measured at $490 \mathrm{~nm}$ for each well with a plate reader.

Lactate dehydrogenase (LDH) assay. PC12 cells $\left(1-1.5 \times 10^{6} / \mathrm{ml}\right)$ were exposed to the different concentrations of 2,5HD (1-10 mmol/l) for $12 \mathrm{~h}$ at $37^{\circ} \mathrm{C}$ in a humidified atmosphere with $5 \% \mathrm{CO}_{2}$. The measurement of LDH leakage was performed using an LDH activity assay kit (Beyotime Institute of Biotechnology), according to the manufacturer's protocols. LDH leakage rates were expressed as the percentage of the total $\mathrm{LDH}$ activity, according to the following equation: $\% \mathrm{LDH}$ release rate $=(\mathrm{LDH}$ activity in medium $/$ total $\mathrm{LDH}$ activity) x $100 \%$.

Measurement of antioxidative enzymes and MDA. The PC12 cells cultured in 24-well plates were treated with 2,5-HD at the concentration of $(1-10 \mathrm{mmol} / \mathrm{l})$ for $12 \mathrm{~h}$ at $37^{\circ} \mathrm{C}$ in a humidified atmosphere with $5 \% \mathrm{CO}_{2}$; the cells were subsequently centrifuged at $251 \mathrm{x}$ g for $10 \mathrm{~min}$ at $4^{\circ} \mathrm{C}$. The cells were lysed in $0.3 \mathrm{ml}$ lysis buffer comprising $0.5 \%$ Triton $\mathrm{X}-100$ in $0.1 \mathrm{~mol} / 1$ potassium phosphate buffer, and homogenized via two freeze/thaw cycles, using sonication (3 sec, $25^{\circ} \mathrm{C}$ ) between the cycles. The homogenate was centrifuged at $1,006 \mathrm{x} \mathrm{g}$ for $20 \mathrm{~min}$ at $4^{\circ} \mathrm{C}$, and the supernatant was subjected to spectrophotometric analysis for thiobarbituric acid reactive substances the activities of antioxidant enzymes, according to the protocols provided by assay kits. In brief, thiobarbituric acid reactive substances were assessed by measuring the MDA concentration at $532 \mathrm{~nm}$. SOD activity was assayed at $550 \mathrm{~nm}$ on the basis of its ability to inhibit the oxidation of hydroxylamine. GSH-Px activity was measured at $412 \mathrm{~nm}$ on the basis of the rate of oxidation of reduced glutathione to oxidized glutathione.

Apoptosis assay. PC12 cells were exposed to the different concentrations of 2,5-HD (1-10 mmol/l) for $12 \mathrm{~h}$, and the apoptotic cells were identified using an annexin V-fluorescein isothiocyanate/propidium iodide (PI) apoptosis kit (Nanjing KeyGen Biotech Co., Ltd.). In brief, the cells (1-1.5x10 $)$ were incubated with $5 \mu \mathrm{l}$ annexin $\mathrm{V}$-fluorescein isothiocyanate and $5 \mu \mathrm{PI}(50 \mathrm{mg} / \mathrm{ml})$ for $20 \mathrm{~min}$ at $25^{\circ} \mathrm{C}$ in the dark, and immediately observed under a fluorescence microscope (BX51, Olympus Corporation; magnification, x200). Three fields of view were analyzed per sample.

Western blot analysis. Total cell lysates were obtained from PC12 cells using radioimmunoprecipitation assay buffer solution (Beyotime Institute of Biotechnology) containing proteinase and phosphatase inhibitors (Beijing Sangon Biotech Co., Ltd.). The protein concentration was determined using a bicinchoninic acid protein assay kit (Sigma-Aldrich; Merck $\mathrm{KGaA}$ ). The supernatant (30 $\mu \mathrm{g}$ protein) from the cell lysates was separated using SDS-PAGE (10\%) and blotted on to polyvinylidene difluoride membranes (Bio-Rad Laboratories, Inc.). The membranes were subsequently blocked with 5\% non-fat milk for $1.5 \mathrm{~h}$ in Tris-buffered saline (TBS)/Tween 20 buffer at $25^{\circ} \mathrm{C}$ and then incubated overnight with the primary antibodies against caspase-3 (1:800), Bax (1:1,000), Bcl-2 (1:900), or $\beta$-actin $(1: 1,500$; used as the control protein for normalization of the blots) at $4^{\circ} \mathrm{C}$. After washing three times 

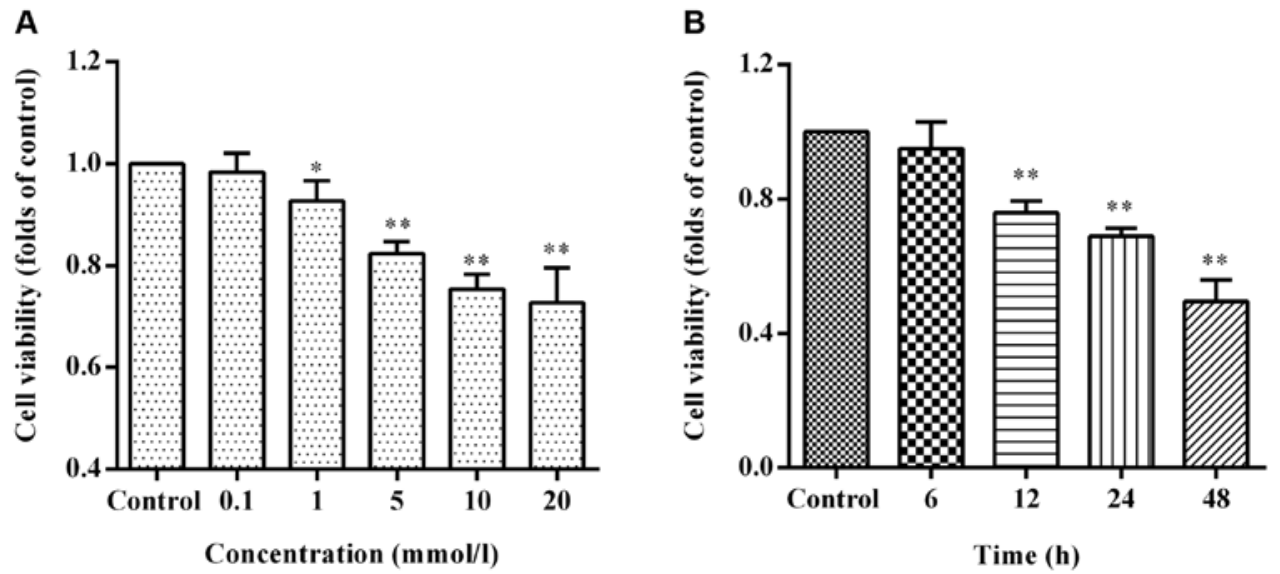

Figure 1. Effect of 2,5-hexanedione on the viability of PC12 cells. The cells were incubated with (A) different concentrations of 2,5-hexanedione for 12 h or (B) $5 \mathrm{mmol} / 12,5$-hexanedione for the indicated durations. Cell viability was subsequently assessed using Cell Counting Kit- 8 assay. The results are expressed as the mean \pm standard error of the mean ( $\mathrm{n}=6$ independent experiments). ${ }^{*} \mathrm{P}<0.05 ;{ }^{* *} \mathrm{P}<0.01$ vs. control.

with TBS, the membranes were incubated at $25^{\circ} \mathrm{C}$ for $3 \mathrm{~h}$ with goat anti-mouse IgG-HRP (1:1,500; cat. no. sc-2005) or goat anti-rabbit IgG-HRP (1:1,500; cat. no. sc-2004); the second antibodies were purchased from Santa Cruz Biotechnology, Inc. Detection of the signal was performed using an enhanced chemiluminescence system (Pierce; Thermo Fisher Scientific, Inc.), and the intensity of the bands was determined via scanning and quantification using the Bio-Rad Gel Doc ${ }^{\mathrm{TM}} 2000$ imaging system (Bio-Rad Laboratories, Inc.).

Statistical analysis. Statistical analyses were performed using GraphPad Prism 6.0 (GraphPad Software, Inc.). All data are presented as the mean \pm standard error of the mean. Steer-Dwass or Mann-Whitney multiplecomparison tests were used to compare the differences among groups. $\mathrm{P}<0.05$ was considered to indicate a statistically significant value.

\section{Results}

Effect of 2,5-HD on the viability of the PC-12 cells. To assess the effect of 2,5-HD on viability of PC12 cells, the cells were initially pretreated with the different concentrations of 2,5-HD (0-20 mol/l) for $12 \mathrm{~h}$, and cell viability was subsequently detected using the CCK-8 method. As presented in Fig. 1A, from a concentration of 2,5-HD $1.0 \mathrm{mmol} / \mathrm{l}$, the viability of PC12 cells significantly decreased in a concentrationdependent manner compared with the control. Additionally, when the cells were treated with $2,5-\mathrm{HD}$ at $5 \mathrm{mmol} / \mathrm{l}$, the viability of the cells significantly decreased from $12 \mathrm{~h}$ of treatment in a time-dependent manner compared with the control (Fig. 1B). Therefore, 2,5-HD may induce injury to PC12 cells.

2,5-HD increases the leakage of LDH of PC12 cells. To further verify the results of the cell viability experiments determined via the CCK-8 method, the leakage of LDH was assayed following treatment with 2,5-HD (1,5 and $10 \mathrm{mmol} / \mathrm{l})$ for $12 \mathrm{~h}$. Our results indicated that 2,5-HD significantly promoted LDH leakage from $5 \mathrm{mmol} / \mathrm{l} 2,5-\mathrm{HD}$, in a concentration-dependent manner compared with the control (Fig. 2). These findings further suggested the damaging effects of 2,5-HD on PC12 cells.

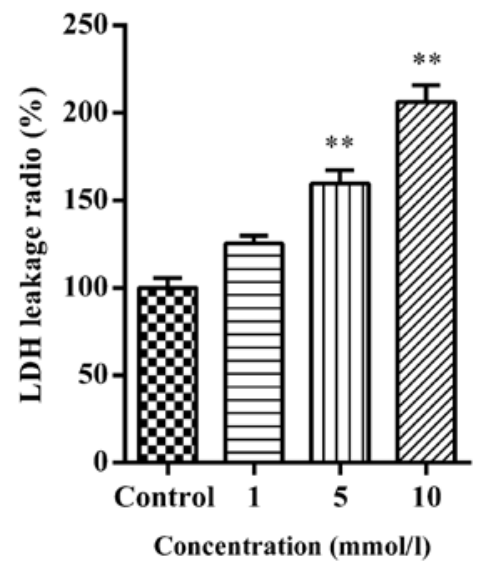

Figure 2. Effects of 2,5hexanedione on the release of LDH from PC12 cells The cells were incubated with the different concentrations of 2,5-hexanedione for $12 \mathrm{~h}$. Subsequently, the release of LDH was assayed using a spectrophotometric method. The results are expressed as the mean \pm standard error of the mean ( $\mathrm{n}=3$ independent experiments). ${ }^{* *} \mathrm{P}<0.05$ vs. control. $\mathrm{LDH}$, lactate dehydrogenase.

2,5-HD promotes the apoptosis of PC12 cells. Following treatment with 2,5-HD, the number of apoptotic cells increased (Fig. 3A). To gain insight into the mechanism of 2,5-HD-induced cell apoptosis, the protein expression levels of cleaved-caspase-3, Bax and Bcl-2 were detected. The results demonstrated that the levels of caspase- 3 and Bax proteins in PC12 cells were significantly increased following treatment with 2,5-HD (5 and $10 \mathrm{mmol} / \mathrm{l}$ ). Conversely, the expression levels of Bcl-2 were significantly decreased following treatment with 5 and $10 \mathrm{mmol} / 12,5-\mathrm{HD}$ compared with the control. These findings further demonstrated that 2,5-HD promotes apoptosis of PC12 cells.

2,5-HD inhibits the activity of antioxidative enzymes and increases the level of MDA. Recent studies have shown that 2,5-HD promotes cell injury via regulating mitochondriadependent apoptosis $(7,27)$. Oxidative stress leads to a state of imbalance between the levels of antioxidants that comprise the defense system and the production of free radicals (28). In the present study, our results demonstrated that 2,5-HD decreased 
A
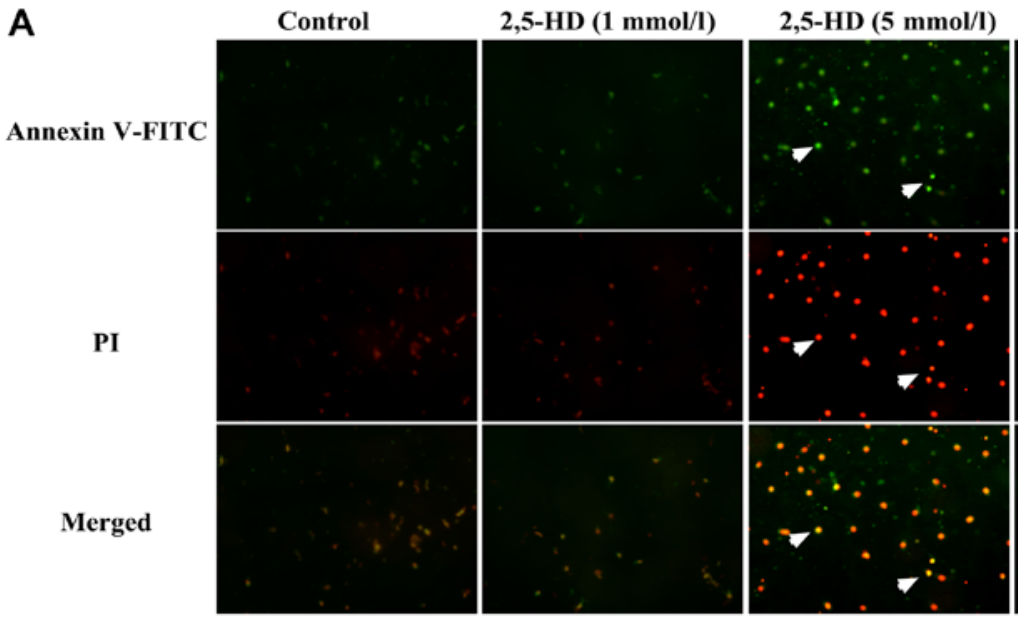

2,5-HD (10 mmol/l)

B
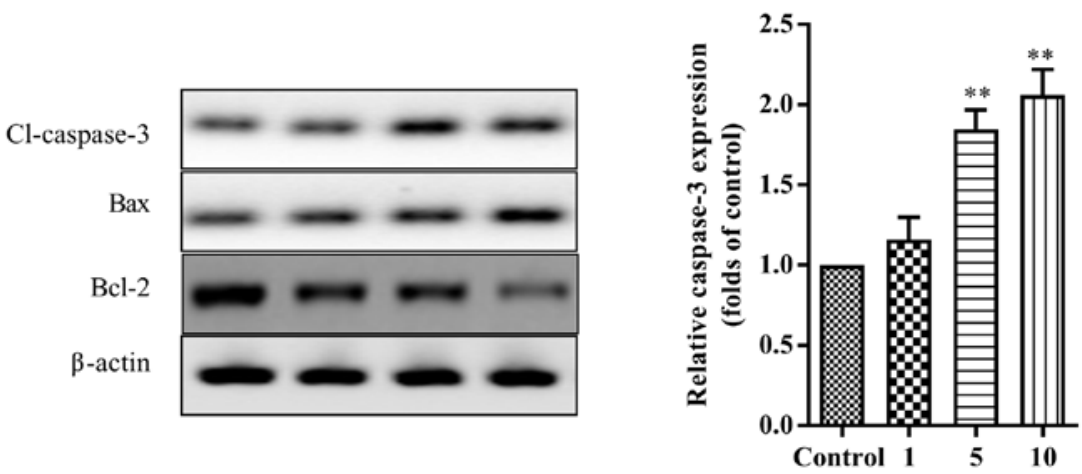

C

D
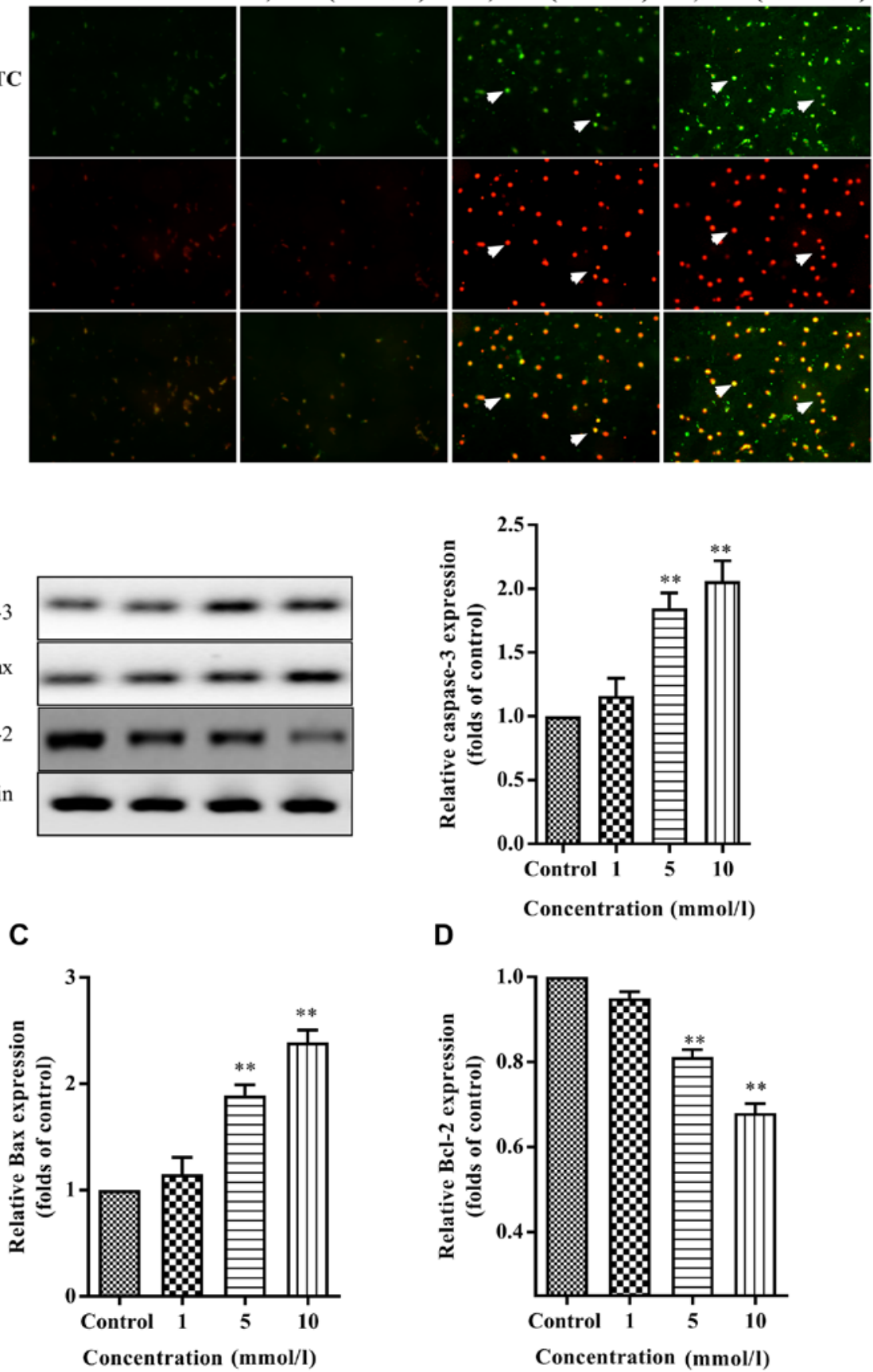

Figure 3. Effects of 2,5-hexanedione on cell apoptosis, and the levels of caspase-3, Bax and Bcl-2. The cells were incubated with the different concentrations of 2,5-hexanedione for $12 \mathrm{~h}$. Subsequently, (A) cell apoptosis was identified via fluorescence microscopy (magnification, x200; green indicated early apoptotic cells and red indicated necrotic cells). The expression levels of (B) Cl-caspase-3, (C) Bax and (D) Bcl-2 were determined by western blotting. The results of three independent western blotting experiments for $\mathrm{Cl}$-caspase-3, Bax and Bcl-2 are shown (expressed as the mean \pm standard error of the mean). ${ }^{* *} \mathrm{P}<0.01$ vs. control. Cl-caspase-3, cleaved-caspase-3; Bax, Bcl-2-associated X protein.

the activity of the antioxidative enzymes, SOD and GSH-Px, in a concentration-dependent manner. On the contrary, $10 \mathrm{mmol} / 12,5$-HD led to a significant increase in the levels of MDA in the supernatant compared with the control (Fig. 4). These results indicated that 2,5-HD was able to induce cell oxidative stress, and that this may account for the mechanism underlying 2,5-HD-induced cell apoptosis.

Antioxidant NAC effectively alleviates 2,5-HD-induced cell apoptosis. To further investigate whether oxidative stress is the underlying cause of 2,5-HD-induced cell apoptosis, the cells were pretreated with the antioxidant NAC $1.5 \mathrm{~h}$ prior to treatment with 2,5-HD. The results demonstrated that NAC was able to effectively decrease the protein levels of 2,5-HD-induced cleaved-caspase-3 and Bax, and increase the expression of Bcl-2. Of note, compared with the control group, antioxidant treatment alone did not alter the levels of cleaved-caspase- 3 and Bax, and Bcl-2. These findings further supported that 2,5-HD-induced cell apoptosis could be mediated via oxidative stress (Fig. 5). 


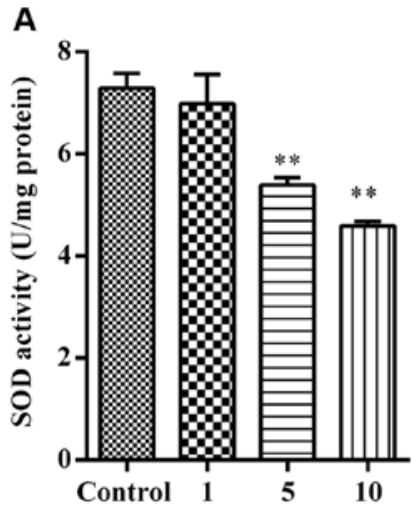

Concentration $(\mathrm{mmol} / \mathrm{l})$

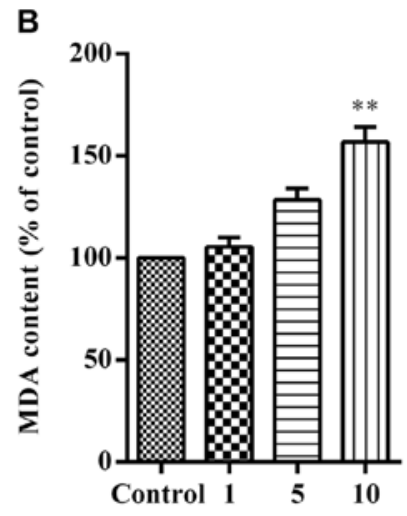

Concentration $(\mathrm{mmol} / \mathrm{l})$

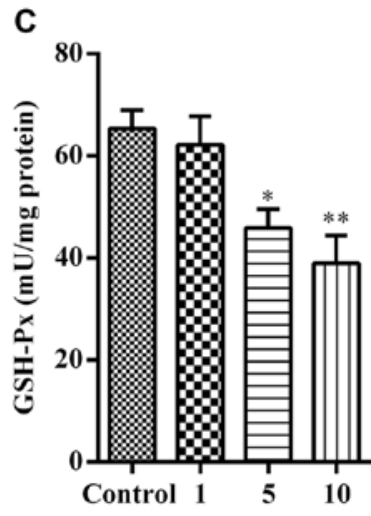

Concentration $(\mathrm{m} \mathrm{mol} / \mathrm{l})$

Figure 4. Effects of 2,5-hexanedione on the activity of antioxidative enzymes and MDA levels. The cells were incubated with different concentrations of 2,5-hexanedione for $12 \mathrm{~h}$. Subsequently, (A-C) the activity of SOD and GSH-Px, and the concentrations of MDA were assayed using a spectrophotometric method. The results of three independent experiments are presented as the mean \pm standard error of the mean. ${ }^{*} \mathrm{P}<0.05 ;{ }^{* *} \mathrm{P}<0.01 \mathrm{vs}$. control. SOD, superoxide dismutase; MDA, malondialdehyde; GSH-Px, glutathione peroxidase.

A
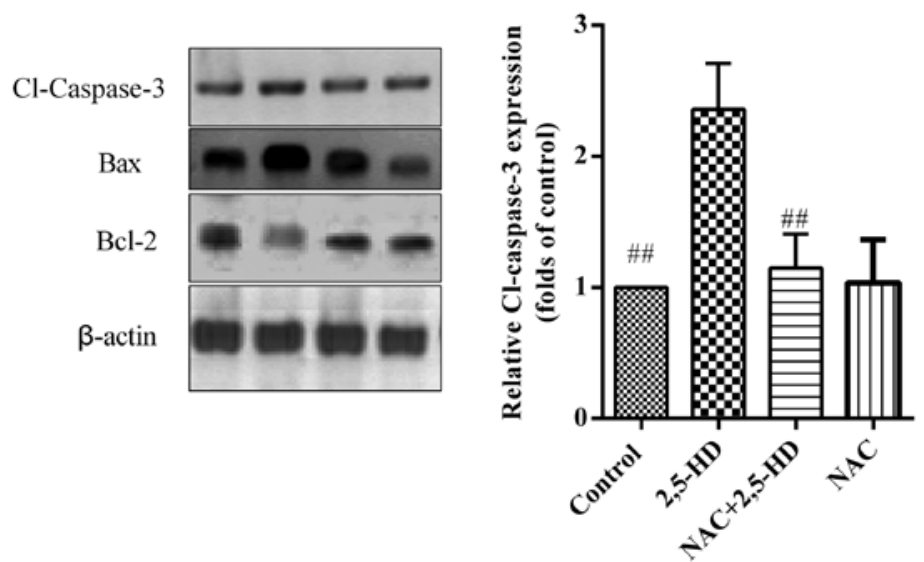

B

C
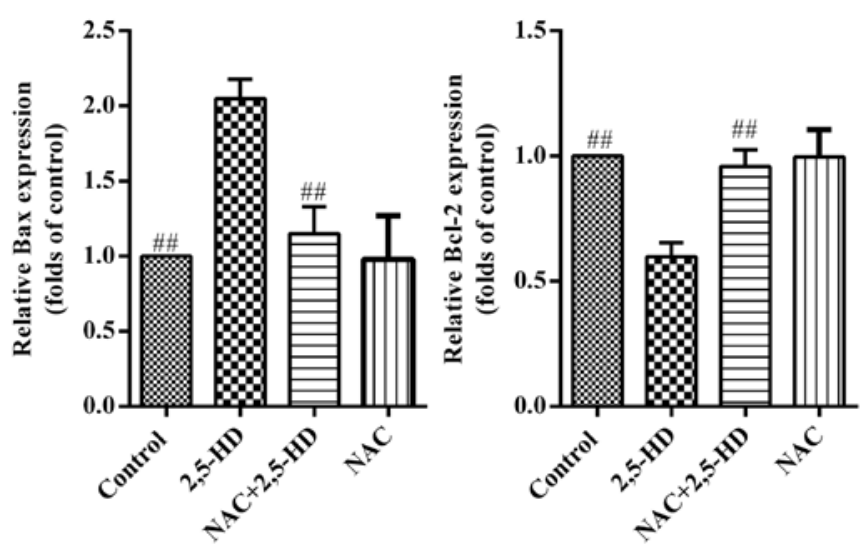

Figure 5. Antioxidant NAC effectively alleviates 2,5-HD-induced cell apoptosis. The cells were pretreated with $10 \mathrm{mmol} / \mathrm{l}$ NAC for $1.5 \mathrm{~h}$. Subsequently, the cells were exposed to $5 \mathrm{mmol} / 1$ 2,5-HD for $12 \mathrm{~h}$, and the expression levels of (A) Cl-caspase-3 (B), Bax and (C) Bcl-2 were assayed by western blot analysis. The results are expressed as the mean \pm standard error of the mean ( $\mathrm{n}=3$ independent experiments). ${ }^{\# \#} \mathrm{P}<0.01$ vs. 2,5 -HD. 2,5 -HD, 2,5 -hexanedione; Bax, Bcl-2-associated X protein; Cl-caspase-3, cleaved-caspase-3; NAC, N-acetylcysteine.

\section{Discussion}

Parkinson's disease, Alzheimer's disease and epilepsy are all neurological disorder diseases, and PC12 cells have served an excellent in vitro model to investigate certain aspects of various neurological disorders (29). 2,5-HD is the most important neurotoxic metabolite of $\mathrm{n}$-hexane, and has elicited notable neurotoxic effects $(30,31)$. The present study revealed that treatment with 2,5-HD led to marked decreases in the viability of PC12 cells and the activity of antioxidant enzymes; 
however, increases in LDH leakage rate and the levels of MDA were noted. The subsequent experiments performed in the present study demonstrated that 2,5-HD upregulated the levels of the proapoptotic proteins, cleaved-caspase-3 and Bax, whereas the level of Bcl-2 was downregulated. Pretreatment of the cells with the antioxidant NAC appeared to have alleviated 2,5-HD-induced cell apoptosis.

Apoptosis occurs in a wide range of physiological and pathological situations (32). It is characterized by cell shrinkage, programmed DNA degradation, and the activation of caspases (33). Downregulation of Bcl-2 and upregulation of Bax is able to induce the release of cytochrome $c$ from the mitochondria into the cytosol, which subsequently triggers the activation of caspase-3, resulting in cell apoptosis (34). The results of the present study demonstrated that the protein levels of proapoptotic cleaved-caspase- 3 and Bax were significantly upregulated, while the expression of Bcl-2 was decreased, following treatment with 2,5-HD.

The abnormal release of $\mathrm{LDH}$ is an index of plasma membrane damage and cell apoptosis (35). Consistently, it has been observed that LDH leakage ratio was significantly increased following exposure to 2,5-HD (5 and $10 \mathrm{mmol} / \mathrm{l})$ for $12 \mathrm{~h}$ in a concentration-dependent manner. ROS serve an important role in cell signaling, mediating numerous pathological and physiological processes, and act as a trigger for cell apoptosis (36). Glutathione serves an important role in shielding cellular macromolecules from endogenous and exogenous reactive oxygen or nitrogen species; another important antioxidative enzyme, SOD, is able to catalyze the dismutation of the superoxide radical $(37,38)$. In the present study, GSH-Px and SOD activity were detected under in vitro conditions. The treatment of PC12 cells with different concentrations of 2,5-HD led to a decrease in the activity of these enzymes. MDA is a highly reactive compound that occurs naturally, and is a marker of oxidative stress (39). The present study revealed that the levels of MDA were markedly increased following cell exposure to different concentrations of 2,5-HD. In the present study, the antioxidant NAC was used to investigate whether ROS serve a role in 2,5-HD-induced cell apoptosis, according to Liu et al (7). Interestingly, pretreatment with the antioxidant NAC led to a marked downregulation in cleaved-caspase-3 and Bax expression, and Bcl-2 expression induced by 2,5-HD. Our findings collectively suggested that the proapoptotic effects of 2,5-HD on PC12 cells may be mediated via oxidative damage. Taken together, these results may provide be applied for the development of novel treatment strategies for neurological disorders.

\section{Acknowledgements}

Not applicable.

\section{Funding}

The present study was supported by the Social Development Grants of Shaanxi Province (grant no. 2012K15-02-04), the Shaanxi Administration of Traditional Chinese Medicine (grant no. JCMS034) and the Xianyang Science and Technology Research and Development Program (grant no. 2017K02-94).

\section{Availability of data and materials}

All data sets used and/or generated during the present study are available from the corresponding author on reasonable request.

\section{Authors' contributions}

SX designed the study and performed experiments. BQ, YL and JW performed experiments and drafted the manuscript, $\mathrm{ZZ}$, JL and JZ contributed to the literature search, performed experiments and interpreted the data. All authors read and approved the final manuscript.

\section{Ethics approval and consent to participate}

Not applicable.

\section{Patient consent for publication}

Not applicable.

\section{Competing interests}

The authors declare that they have no competing interests.

\section{References}

1. Zhang TL, Han XY, Zhao XL, Zhao L, Zhang CL, Yu LH, Yu SF and Xie KQ: 2,5-Hexanedione induced reduction in protein content and mRNA expression of neurofilament in rat cerebral cortex. Environ Toxicol Pharmacol 20: 92-98, 2005.

2. Sabyrov K, Jiang J, Yaghi OM and Somorjai GA: Hydroisomerization of $n$-hexane using acidified metal-organic framework and platinum nanoparticles. J Am Chem Soc 139: 12382-12385, 2017.

3. Puri V, Gupta AD, Chaudhry N and Saran RK: Reversible cerebral and brain stem dysfunction in n: Hexane neuropathy. Ann Indian Acad Neurol 18: 464-467, 2015.

4. Guimaraes-Costa R, Schoindre Y, Metlaine A, Lefaucheur JP, Camdessanché JP, Maisonobe T and Léger JM: N-hexane exposure: A cause of small fiber neuropathy. J Peripher Nerv Syst 23: 143-146, 2018.

5. Boekelheide K, Fleming SL, Allio T, Embree-Ku ME, Hall SJ, Johnson KJ, Kwon EJ, Patel SR, Rasoulpour RJ, Schoenfeld HA and Thompson S: 2,5-hexanedioneinduced testicular injury. Annu Rev Pharmacol Toxicol 43: 125-147, 2003.

6. Xing-Fu P, Ya-Ling Q, Wei Z, Hong-Fang T, Zheng R, Bang-Hua W, Han-Lin H, Yu-Xin Z and Hui-Fang Y: Determination of total urinary 2,5-hexanedione in the Chinese general population. Environ Res 150: 645-650, 2016.

7. Liu S, Chen F, Wang L, Sun W, Liu Q, Chen H, Su D, Jiang Y, Piao F, Sun X and Sun W: 2,5-hexanedione induced apoptosis of rat bone marrow mesenchymal stem cells by reactive oxygen species. J Occup Health 58: 170-178, 2016.

8. Brenner C and Kroemer G: Apoptosis. Mitochondria-the death signal integrators. Science 289: 1150-1151, 2000

9. McArthur K, Whitehead LW, Heddleston JM, Li L, Padman BS, Oorschot V, Geoghegan ND, Chappaz S, Davidson S, San Chin $\mathrm{H}$, et al: BAK/BAX macropores facilitate mitochondrial herniation and mtDNA efflux during apoptosis. Science 359: pii: eaao6047, 2018.

10. Scorrano L, Oakes SA, Opferman JT, Cheng EH, Sorcinelli MD, Pozzan $\mathrm{T}$ and Korsmeyer SJ: BAX and BAK regulation of endoplasmic reticulum $\mathrm{Ca} 2+$ : A control point for apoptosis. Science 300: 135-139, 2003.

11. Zhang C, Hou L, Yang J, Che Y, Sun F, Li H and Wang Q: 2,5-Hexanedione induces dopaminergic neurodegeneration through integrin $\alpha \mathrm{M} \beta 2 / \mathrm{NADPH}$ oxidase axis-mediated microglial activation. Cell Death Dis 9: 60, 2018. 
12. Sharma Y, Srivastava N and Bala K: Neuroprotective ability of TMV coat protein on rat PC-12 cells and it's in silico study with LRRK2 receptor. Neurol Res 40: 1028-1039, 2018.

13. Yu W, Lv Z, Zhang L, Gao Z, Chen X, Yang X and Zhong M: Astragaloside IV reduces the hypoxiainduced injury in PC-12 cells by inhibiting expression of miR-124. Biomed Pharmacother 106: 419-425, 2018.

14. Wang X, Zhu G, Yang S, Wang X, Cheng H, Wang F, Li X and Li Q: Paeonol prevents excitotoxicity in rat pheochromocytoma PC12 cells via downregulation of ERK activation and inhibition of apoptosis. Planta Med 77: 1695-1701, 2011.

15. Yang CP, Zhang ZH, Zhang LH and Rui HC: Neuroprotective Role of MicroRNA-22 in a 6-hydroxydopamine-induced cell model of parkinson's disease via regulation of its target gene TRPM7. J Mol Neurosci 60: 445-452, 2016.

16. Jesko H, Wilkaniec A, Cieslik M, Hilgier W, Gąssowska M, Lukiw WJ and Adamczyk A: Altered arginine metabolism in cells transfected with human wildtype beta amyloid precursor protein ( $\beta$ APP). Curr Alzheimer Res 13: 1030-1039, 2016

17. Huang NK, Lin YL, Cheng JJ and Lai WL: Gastrodia elata prevents rat pheochromocytoma cells from serum-deprived apoptosis: The role of the MAPK family. Life Sci 75: 1649-1657, 2004.

18. Seki K, Cueno ME, Kamio N, Saito Y, Kamimoto A, KuritaOchiai $\mathrm{T}$ and Ochiai $\mathrm{K}$ : Varying butyric acid amounts induce different stress- and cell death-related signals in nerve growth factortreated PC12 cells: Implications in neuropathic pain absence during periodontal disease progression. Apoptosis 21: 699-707, 2016

19. Huang CL, Wang KC, Yang YC, Chiou CT, Tan CH, Lin YL and Huang NK: Gastrodia elata alleviates mutant huntingtin aggregation through mitochondrial function and biogenesis mediation. Phytomedicine 39: 75-84, 2018.

20. Gozal E, Metz CJ, Dematteis M, Sachleben LR Jr, Schurr A and Rane MJ: PKA activity exacerbates hypoxiainduced ROS formation and hypoxic injury in PC-12 cells. Toxicol Lett 279: 107-114, 2017.

21. Kahn LG and Trasande L: Environmental toxicant exposure and hypertensive disorders of pregnancy: Recent Findings. Curr Hypertension Rep 20: 87, 2018.

22. Chen QS, Wang QW, Zhu JH, Xiao QZ and Zhang L: Reactive oxygen species: Key regulators in vascular health and diseases. Brit J Pharmacol 175: 1279-1292, 2018.

23. Bondy SC: Anthropogenic pollutants may increase the incidence of neurodegenerative disease in an aging population. Toxicology 341-343: 4146, 2016.

24. Xu B, Xu ZF, Deng Y, Liu W, Yang HB and Wei YG: Protective effects of MK-801 on methylmercury-induced neuronal injury in rat cerebral cortex: Involvement of oxidative stress and glutamate metabolism dysfunction. Toxicology 300: 112120, 2012.

25. Yankner BA, Dawes LR, Fisher S, Villa-Komaroff L, Oster-Granite ML and Neve RL: Neurotoxicity of a fragment of the amyloid precursor associated with Alzheimer's disease. Science 245: 417-420, 1989.
26. Li Y, Walker DW and King MA: Peroxide mediates ethanolinduced cytotoxicity in PC12 cells. Free Radic Biol Med 30: 389-392, 2001

27. Li S, Guan H, Qian Z, Sun Y, Gao C, Li G, Yang Y, Piao F and $\mathrm{Hu}$ S: Taurine inhibits 2,5-hexanedione-induced oxidative stress and mitochondria-dependent apoptosis in PC12 cells. Ind Health 55: 108-118, 2017.

28. Forrester SJ, Kikuchi DS, Hernandes MS, Xu Q and Griendling KK: Reactive oxygen species in metabolic and inflammatory signaling. Circ Res 122: 877-902, 2018.

29. Spicer Z and Millhorn DE: Oxygen sensing in neuroendocrine cells and other cell types: Pheochromocytoma (PC12) cells as an experimental model. Endocr Pathol 14: 277-291, 2003.

30. Gillies PJ, Norton RM and Bus JS: Effect of 2,5-Hexanedione on lipid biosynthesis in sciatic nerve and brain of the rat. Toxicol Appl Pharmacol 54: 210-216, 1980.

31. Rossi A, Simonati A, Rizzuto N and Toschi G: Neurotoxic action of 2,5hexanedione on the autonomic nervous system: Ultrastructural and functional alterations in the rat sympathetic superior cervical ganglion. Brain Res 243: 373-377, 1982.

32. Cheng $X$ and Ferrell JE Jr: Apoptosis propagates through the cytoplasm as trigger waves. Science 361: 607-612, 2018.

33. Thompson CB: Apoptosis in the pathogenesis and treatment of disease. Science 267: 1456-1462, 1995.

34. Spierings D, McStay G, Saleh M, Bender C, Chipuk J, Maurer U and Green DR: Connected to death: The (unexpurgated) mitochondrial pathway of apoptosis. Science 310: 66-67, 2005.

35. Mao W and Zhu Z: Parthenolide inhibits hydrogen peroxideinduced osteoblast apoptosis. Mol Med Rep 17: 8369-8376, 2018.

36. Giorgio M, Migliaccio E, Orsini F, Paolucci D, Moroni M, Contursi C, Pelliccia G, Luzi L, Minucci S, Marcaccio M, et al: Electron transfer between cytochrome $\mathrm{c}$ and p66Shc generates reactive oxygen species that trigger mitochondrial apoptosis. Cell 122: 221-233, 2005

37. St-Pierre J, Drori S, Uldry M, Silvaggi JM, Rhee J, Jäger S, Handschin C, Zheng K, Lin J, Yang W, et al: Suppression of reactive oxygen species and neurodegeneration by the PGC-1 transcriptional coactivators. Cell 127: 397-408, 2006.

38. Kane DJ, Sarafian TA, Anton R, Hahn H, Gralla EB, Valentine JS, Ord T and Bredesen DE: Bcl-2 inhibition of neural death: Decreased generation of reactive oxygen species. Science 262: 1274-1277, 1993.

39. Nesnow S, Grindstaff RD, Lambert G, Padgett WT, Bruno M, Ge Y, Chen PJ, Wood CE and Murphy L: Propiconazole increases reactive oxygen species levels in mouse hepatic cells in culture and in mouse liver by a cytochrome P450 enzyme mediated process. Chem Biol Interact 194: 79-89, 2011.

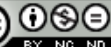

This work is licensed under a Creative Commons Attribution-NonCommercial-NoDerivatives 4.0 International (CC BY-NC-ND 4.0) License. 